\title{
PENGEMBANGAN PERANGKAT PEMBELAJARAN IPA MODEL PROYEK UNTUK MELATIHKAN BERPIKIR KREATIF SISWA SMP MATERI GERAK BENDA
}

\author{
Karlin$^{1}$, Wahono Widodo², Madlazim³ \\ ${ }^{1)}$ Mahasiswa Program Studi Pendidikan Dasar, Program Pascasarjana Universitas Negeri Surabaya \\ 2), 3)Dosen Pascasarjana Prodi Pendidikan Sains Univesrtitas Negeri Surabaya \\ e-mail:Karlin_75@yahoo.co.id
}

\begin{abstract}
This research aims to develop valid, practical, and effective science learning material using project learning model to facilitate creative thinking skills on object motion in junior high school. Design of the development are used follow 4D model desin. The learning kit being validated by experts are syllabus, lesson plan, student work sheet, handout, and creative thinking question. The objective of this research was to trial learning materials in 39 grade VIII students in SMPN 31 Surabaya with One Group Pretest Postes Design. The results were analyzed by descriptive quantitative and qualitative. The result were obtained shows that the developed learning materials are: (1) Validity of learning material valid category $(3,58)$; $(2)$ Practicality based on: a) Feasibility of instruction good category $(3,9)$; b) Readability of worksheets and student's book students stating that the content and appearance of worksheets and student's book good category; (3) Effectiveness based on: a) Student's activities high category $(93 \%)$; b) Result of creative thinking students increased with medium category $(N$-Gain: 0,62$)$, result of creative thinking students increased with medium category $(N$-Gain:0,674) in fluency thinking aspect, result of creative thinking students increased with high category $(N$-Gain:0,726) in flexible thinking aspect, result of creative thinking students increased with medium category $(N$-Gain:0,531) in original thinking aspect, and result of creative thinking students increased with medium category $(N$ Gain:0,530) in elaboration thinking aspect; c)The response of students very positively $(92 \%)$. The conclusion of this research that science learning material developed base on project learning model valid, practical, and effective to facilitate student's creative thinking in junior high school.
\end{abstract}

Key word: Learning Model Project, Creative Thinking

Abstrak: Penelitian ini bertujuan mengembangkan perangkat pembelajaranIPA model proyek yang valid, praktis, dan efektif untuk melatihkan berpikir kreatif siswa SMP materi gerak benda. Rancangan pengembangan yang digunakan mengikuti rancanagn model 4D. Perangkat pembelajaran yang dikembangkan meliputi Silabus, RPP, Handout siswa, LKP, dan Soal berpikir kreatif. Sasaran penelitian adalah perangkat pembelajaran yang diujicobakan pada 39 siswa kelas VIII SMPN 31 Surabaya dengan rancangan menggunakan One Group Pretest-Postest Design. Hasil penelitian dianalisis secara deskriptif kuantitatif dan kualitatif. Hasil yang diperoleh menunjukkan bahwa perangkat pembelajaran yang dikembangkan dinyatakan: (1) Validitas perangkat kategori valid (3,58); (2) Kepraktisan perangkat yang meliputi: a) Keterlaksanaan baik $(3,9)$; b)Keterbacaan Handout dan LKP baik; (3) Keefektifan perangkat pembelajaran yang meliputi: a) Aktivitas siswa dengan kategori tinggi (93\%); b) Hasil berpikir kreatif siswa mengalami peningkatan dengan kategori sedang (N-Gain: 0,62), pada aspek berpikir lancar (fluent) mengalami peningkatan berkategori sedang (N-Gain: 0,674), berpikir luwes (flexible) mengalami peningkatan berkategori tinggi (N-Gain: 0.726), berpikir orisinal (original) mengalami peningkatan berkategori sedang (N-Gain: 0,531), dan berpikir terperinci (elaboration) mengalami peningkatan berkategori sedang (N-Gain: 0,530); c) Respon siswa terhadap perangkat dan model pembelajaran sangat positif (92\%). Simpulan penelitian ini bahwa perangkat pembelajaran IPA model proyek valid, praktis, dan efektif untuk melatihkan berpikir kreatif siswa SMP.

Kata kunci: Pembelajaran Model Proyek, Berpikir Kreatif

\section{PENDAHULUAN}

Sains adalah salah satu aspek pendidikan yang digunakan sebagai alat untuk mencapai tujuan pendidikan. Sains tidak hanya terdiri dari fakta, konsep, tetapi juga merupakan sekumpulan pengetahuan yang mengandung empat hal yaitu: produk, proses, sikap dan teknologi. (Carin, 1993). Proses pembelajaran diselenggarakan secara interaktif, inspiratif, menyenangkan, menantang, memotivasi peserta didik untuk aktif serta memberikan ruang yang cukup bagi prakarsa, kreativitas, dan kemandirian sesuai dengan bakat, minat, dan perkembangan fisik serta psikologis peserta didik, sehingga hal ini sejalan dengan Peraturan Pemerintah Nomor 32 Tahun 2013.

Hasil temuan menyatakan bahwa kegiatan pembelajaran yang dilaksanakan oleh guru masih cenderung prosedural dan lebih menekankan pada hasil belajar. Siswa kurang berkesempatan untuk mengembangkan kreativitas dan produktivitas berpikirnya dan cenderung lebih mengutamakan 
pengembangan kemampuan kognitif (Risnanosanti, 2009). Hal ini membuat para siswa seringkali mengalami kebingungan saat harus menyelesaikan masalah secara nyata, karena tidak semua masalah dapat diselesaikan secara efektif dengan menggunakan kemampuan kognitif saja.

Berdasarkan hasil observasi pra-penelitian di SMP Negeri 31 Surabaya pada tes berpikir kreatif yang indikatornya fluency, flexibility, originality, elaboration pada siswa kelas VIII-A, didapatkan bahwa $71 \%$ siswa memiliki kriteria kurang kreatif dan hanya $29 \%$ siswa yang memiliki kriteria cukup kreatif. Berdasarkan hasil tersebut, menyatakan bahwa siswa SMP Negeri 31 Surabaya, belum dapat berpikir secara kreatif karena sebagian besar mereka hanya mengandalkan bantuan teman saat mengerjakan soal, belum lancar (fluent) dalam mengemukakan pendapat atau ide karena hanya menggunakan rumus yang telah tersedia saja, belum dapat untuk berpikir kreatif dalam memberikan gagasan asli (original) secara unik dan siswa juga belum dapat berpikir kreatif untuk melengkapi (elaboration) soal dengan cerita selengkap-lengkapnya.

Berpikir kreatif adalah kebiasaan dari pikiran yang selalu dilatih untuk memperhatikan intuisi, menghidupkan imajinasi, mengungkapkan kemungkinan-kemungkinan baru, dan membangkitkan ide-ide yang tidak terduga (Asmani, 2013). Berpikir keatif merupakan salah satu tahapan berpikir tingkat tinggi yang diperlukan dalam kehidupan masyarakat, dan selalu dihadapkan pada permasalahan sehingga diperlukan kreativitas untuk memecahkan permasalahan tersebut (Rohim, dkk, 2012). Kreativitas ini dapat diperoleh dari kecakapan kognitif, sehingga untuk menjadi kreatif maka dapat diperoleh dari hasil belajar kognitif (Daryanto, 2009).

Keberhasilan proses dan hasil belajar mengajar tidak terlepas dari peran guru yang selalu mengharapkan ilmu pengetahuan dan ketrampilan yang telah diajarkannya agar dapat diterima dan dikembangkan oleh siswa dengan baik dan kreatif. Pembelajaran yang melibatkan individu secara aktif dalam menanggapi informasi dan situasi dapat digunakan saat bekerja dengan kelompok kecil atau seluruh kelas sehingga tujuan pembelajaran dapat tercapai (Diamond, 2006).

Model pembelajaran proyek adalah suatu pendekatan pengajaran yang komprehensif dengan merancang lingkungan belajar siswa untuk dapat melakukan penyelidikan terhadap masalah autentik termasuk pendalaman materi dari suatu topik mata pelajaran dan melaksanakan tugas bermakna lainnya yang memperkenankan siswa untuk bekerja secara mandiri dan mengkonstruksi pembelajarannya dan mengkulminasikannya dalam produk nyata (Bluck Institute for Education dalam Khaeruddin 2005).
Keberhasilan siswa dalam memahami materi pelajaran tergantung pada guru sebagai pembimbing yang harus bertindak sebagai motivator dan fasilitator yang baik (Munandar, 2009).

Materi gerak benda pada siswa SMP kelas VIII semester genap yaitu gerak lurus beraturan dan gerak lurus berubah beraturan. Perbedaan antara gerak lurus beraturan dan gerak lurus berubah beraturan dengan indikator berpikir kreatif diharapkan dapat diajarkan melalui pembelajaran dengan model proyek.

Kurikulum 2013 mengamanahkan bahwa pembelajaran harus dapat memberikan manfaat pada sekolah untuk menjembatani kesenjangan antara ilmu pengetahuan dan ketrampilan. Buku Guru Kurikulum 2013 telah menyediakan sintaks beserta format untuk penilaian pembelajaran proyek dan pada materi gerak benda juga telah terdapat penilaian pengetahuan proyek. Sintaks dan penilaian pembelajaran proyek tersebut dalam melaksanakannya diperlukan perangkat pembelajaran diantaranya yaitu Rencana Pelaksanaan Pembelajaran dan Lembar Kerja siswa, sehingga peneliti tertarik untuk melakukan penelitian pengembangan yang berkaitan dengan pembelajaran model proyek untuk melatihkan berpikir kreatif terhadap siswa.

Berdasarkan uraian di atas maka peneliti bermaksud melakukan penelitian dengan judul "Pengembangan Perangkat Pembelajaran IPA Model Proyek untuk Melatihkan Berpikir Kreatif Siswa SMP materi Gerak Benda”.

\section{METODE PENELITIAN}

Penelitian ini merupakan jenis penelitian pengembangan, yaitu mengembangkan perangkat pembelajaran yang mengacu pada model pengembangan perangkat 4D (four $D$ model) yang meliputi pendefinisian (define), perancangan (design), pengembangan (develop), dan penyebaran (Disseminate).

Ujicoba penelitian ini dilakukan pada 39 orang siswa kelas VIII-A SMP Negeri 31 Surabaya Tahun Pelajaran 2014-2015 dengan menggunakan rancangan penelitian One-Group Pretest-Postest Design, karena penelitian ini hanya menggunakan satu kelompok saja tanpa adanya kelompok pembanding. Instrumen penelitian ini kemudian di validasi oleh dua pakar pendidikan. Teknik pengambilan data pada penelitian ini adalah dengan observasi, tes dan angket. Materi yang dikembangkan adalah materi gerak benda yaitu gerak dan kecepatan, gerak lurus beraturan, dan gerak lurus berubah beraturan.

\section{HASIL PENELITIAN DAN DISKUSI}

Berdasarkan hasil uji coba II perangkat pembelajaran yang telah dikembangkan dan 
diimplementasikan di SMP Negeri 31 Surabaya berupa: Validitas perangkat pembelajaran (Silabus, RPP, Handout siswa, Lembar Kerja Proyek siswa, Soal Tes Berpikir Kreatif), Kepraktisan Perangkat Pembelajaran (keterlaksanaan pembelajaran, keterbacaan Handout siswa, keterbacaan Lembar Kerja Proyek siswa) dan Keefektifan Perangkat Pembelajaran (Aktivitas siswa, kemampuan berpikir kreatif siswa, dan respon siswa) serta kendala-kendala yang ditemui selama pembelajaran akan ditampilkan berikut ini:

\section{A. Validitas Perangkat Pembalajaran}

Validasi perangkat pembelajaran yang dikembangkan diperoleh hasil sebagai berikut: Validasi Silabus memenuhi ketegori baik, RPP yang disusun memiliki kategori baik, Validasi Handout siswa yang digunakan memiliki kategori baik, validasi LKP berkategori sangat baik, hasil validasi Tes Berpikir Kreatif pada aspek materi, kontruksi dan bahasa berkategori valid.

\section{B. Kepraktisan Perangkat Pembelajaran}

Kepraktisan perangkat pembelajaran dalam penelitian ini ditinjau dari keterlaksanaan pembelajaran, keterbacaan Handout dan keterbacaan Lembar Kerja Proyek Siswa.

1. Keterlaksanaan Pembelajaran

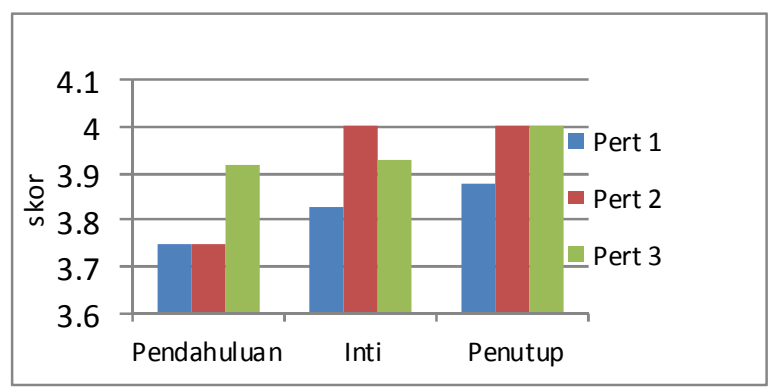

Gambar 1. Grafik Keterlaksanaan Pembelajaran

Kegiatan pembelajaran dalam RPP yang dikembangkan meliputi kegiatan pendahuluan, inti, dan penutup. Kegiatan-kegiatan pembelajaran tersebut mencakup model, metode, dan sintak-sintak atau langkah-langkah pembelajaran. Sintak/langkah pembelajaran yang digunakan untuk mencapai tujuan pembelajaran yang telah ditetapkan mengacu pada model pembelajaran proyek. Kepraktisan perangkat pembelajaran dapat diketahui dari keterlaksanaan RPP pada pertemuan pertama, kedua, dan ketiga yang terlaksana dengan baik.

Kegiatan pendahuluan dengan kategori sangat baik yang berarti guru telah melaksanakan pembelajaran dengan baik meliputi kegiatan membimbing dan mengkondisikan siswa untuk melakukan kegiatan belajar mengajar dengan berdoa bersama, mengabsen, menyapa siswa dan membagikan Handout siswa, memotivasi siswa, menyampaikan tujuan pembelajaran, menyampaikan materi, menyampaikan model pembelajaran proyek, dan teknik penilaian peserta didik, sehingga berdampak pada antusias siswa ketika mengikuti pembelajaran dengan semangat, hal ini dapat dilihat dari ketertarikan siswa pada proses pembelajaran.

Kegiatan inti dengan kategori sangat baik yang berarti guru telah melakukan kegiatan inti yaitu menyampaikan soal dari kegiatan proyek, mempersilahkan siswa bertanya, membentuk kelompok kerja, memberikan kesempatan untuk menentukan ketua kelompok, membagikan Lembar Kerja Proyek, memberikan pertanyaan untuk menggambar lintasan gerak, membuat proyek GLB dan GLBB, mengarahkan ketua kelompok untuk memberikan masukan kepada anggota yang kurang tepat dalam melaksanakan proyek, menyusun jadwal dan alokasi waktu kegiatan proyek, memantau siswa dalam menyusun langkah kerja proyek secara flexible, memantau siswa dalam membuat rumusan masalah secara flexible, memantau siswa merumuskan hipotesis dan menentukan variabel pada kegiatan proyek, menilai produk siswa untuk menghitung (jarak, perpindahan, kecepatan, kelajuan), membuat grafik kecepatan terhadap waktu pada GLB dan GLBB, menguji hasil produk siswa dalam tabel data pengamatan, melakukan evaluasi pengalaman siswa untuk menyimpulkan hasil pengamatan siswa secara elaboration, meminta siswa mempresentasikan hasil kegiatan proyek, menugaskan siswa untuk membuat laporan hasil kegiatan proyek, dan membagikan lembar penilaian sikap siswa oleh diri dan sejawat.

Kegiatan penutup dengan kategori sangat baik yang berarti guru mampu melakukan kegiatan penutup dengan baik yaitu mempersilahkan siswa untuk menarik kesimpulan, menyampaikan penghargaan kepada kelompok siswa, melatih kreatif siswa dengan mengerjakan soal formatif, dan guru menyampaikan materi untuk pertemuan selanjutnya.

Berdasarkan pembahasan di atas dapat diketahui bahwa perangkat RPP yang dikembangkan merupakan perangkat yang reliabel dan memiliki kategori yang baik sehingga layak untuk melatihkan berpikir kreatif siswa.

\section{Keterbacaan Handout dan LKP}

Handout dapat menunjang siswa dalam berpikir kreatif pada saat pembelajaran, karena handout tersedia latihan soal formatif untuk melatihkan berpikir kreatif. Siswa yang dapat menjawab pertanyaan pada handout juga dapat menjawab soal tes berpikir kreatif pada akhir pembelajaran dan hal ini didukung dengan penelitian (Klieger, 2015) menyatakan buku teks dilengkapi dengan bahan pengajaran yang dapat melatih berpikir kreatif siswa. Hal ini jelas bahwa ilustrasi dalam handout dapat berkontribusi pada proses pembelajaran 
dalam pendidikan IPA. LKP yang mendesain langkahlangkah pembelajaran model proyek dapat melatihkan berpikir kreatif siswa. Secara keseluruhan siswa tertarik dan mudah memahami isi LKP tersebut dan mampu membantu siswa dalam kegiatan proyek penyelidikan, memotivasi belajar siswa, menjadikan siswa lebih aktif dalam proses belajar dan melatih berpikir kreatif siswa. Hal ini sesuai dengan teori Dual Colding, informasi yang disajikan baik secara visual maupun verbal diingat lebih baik daripada informasi yang hanya disajikan dengan salah satu cara (Slavin, 2006: 176).

\section{Kefektifan Perangkat Pembelajaran}

Keefektifan perangkat pembelajaran yang dikembangkan ditinjau dari aktivitas siswa selama proses pembelajaran, hasil tes kemampuan berpikir kreatif siswa, dan respon siswa.

\section{Aktivitas Siswa}

Aktivitas siswa dalam pembelajaran ini adalah rangkaian kegiatan yang dilakukan siswa selama mengikuti pembelajaran model proyek pada pokok bahasan Gerak dan Kecepatan, Gerak Lurus Beraturan (GLB) dan Gerak Lurus Berubah Beraturan (GLBB) yang diukur menggunakan 11 aspek aktivitas siswa yaitu membuat proyek sederhana gambar lintasan gerak, mempersiapkan alat dan bahan, merumuskan masalah, merumuskan hipotesis, mendefinisikan variabel, penanggung jawab kegiatan, menyebutkan langkah kerja proyek, menghasilkan data kerja, menganalisis data, pembahasan hasil data, dan merumuskan kesimpulan. Berikut disajikan gambar diagram aktivitas siswa selama proses pembelajaran.

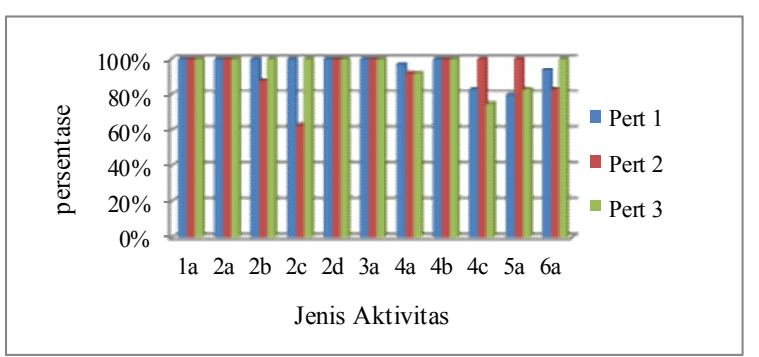

Gambar 2. Diagram Aktivitas Siswa

Hasil analisis aktivitas siswa selama pelaksanaan proyek diketahui bahwa rata-rata aktivitas siswa mencapai 93\%. Hasil tersebut menunjukkan bahwa aktivitas siswa selama proses pelaksanaan proyek, siswa aktif berpartisipasi. Hasil ini sesuai dengan pendapat Slavin (2011) bahwa siswa harus membangun pengetahuan dalam pikiran mereka sendiri, guru dapat memfasilitasi proses ini dengan cara mengajar cara-cara yang menjadikan informasi bermakna dan relevan bagi siswa, dengan memberi kesempatan kepada siswa menemukan atau menerapkan sendiri gagasan-gagasan, mengetahui dan menggunakan strategi mereka sendiri. Hal ini juga sesuai dengan hasil penelitian yang dilakukan oleh Purwanto (2014) bahwa aktivitas siswa meningkat dengan pembelajaran model proyek.

Proyek adalah tugas yang harus diselesaikan kelompok siswa dalam periode waktu tertentu. Tugas tersebut berupa suatu investigasi sejak dari perencanaan, pengumpulan, pengorganisasian, pengolahan dan penyajian data proyek (Buku Guru 8, 2014:40). Aktivitas proyek yang dilakukan siswa tersebut diarahkan untuk aktif beraktivitas dalam belajar sehingga dapat meningkatkan kinerja siswa serta guru berperan sebagai fasilitator dan evaluator terhadap proses dan produk proyek yang dihasilkan oleh kelompok siswa.

Mengingat siswa yang dijadikan subjek penelitian adalah siswa SMP yang belum pernah merumuskan hipotesis suatu penyelidikan, sehingga bimbingan yang intensif masih diperlukan. Bantuan yang berupa bimbingan dikurangi secara bertahap sehingga pada gilirannya nanti siswa dapat mengambil alih tanggung jawabnya dan mampu secara mandiri melaksanakan penyelidikan. Hasil penelitian Liu (2007) bahwa melalui suatu aktivitas siswa, maka siswa dapat mengkonstruksi pengetahuannya sendiri dan bermakna melalui pengalaman yang nyata.

Setiap pertemuan terdapat aktivitas yang tidak relevan, aktivitas ini ditandai dengan siswa yang bermain dan berbicara diluar topik yang dipelajari. Rata-rata aktivitas yang tidak relevan sebesar 7\% dan dapat diantisipasi dengan memberikan tanggung jawab kepada kelompok siswa untuk melaksanakan tugas dan mempresentasikan hasil kerja proyek yang dikerjakannya.

2. Hasil Tes Kemampuan Berpikir Kreatif Siswa

Kemampuan berpikir kreatif siswa diukur dengan melakukan tes berpikir kreatif. Tes berpikir kreatif dilakukan dua kali sebelum dan sesudah pembelajaran bertujuan untuk mengukur berpikir kreatif siswa setelah melakukan pembelajaran proyek. Tes berpikir kreatif ini berjumlah 4 soal uraian. Soal pertama indikator yang diukur adalah Fluency (kemampuan untuk menghasilkan banyak gagasan), soal kedua indikator yang diukur adalah Flexibility (kemampuan untuk menggunakan berbagai macam pendekatan dalam mengatasi masalah), soal ketiga indikator yang diukur adalah Originality (keaslian ide yang dibuat dalam merespon perintah), soal keempat indikator yang diukur adalah Elaboration (kemampuan dalam memberikan gagasan secara terperinci).

Menurut Munandar (2009) dalam pengembangan kreativitas yang berasumsi bahwa setiap orang pada dasarnya memiliki potensi kreatif dan kemampuan untuk mengungkapkan dirinya secara kreatif, sehingga digunakan pendekatan empat $P$ yaitu Pribadi, Pendorong, Proses, dan Produk. Menurut (Ong \& Borich, 2000) berpikir kreatif mengharuskan siswa 
menerima pengetahuan untuk menghasilkan pengetahuan baru dan hubungan baru. Tipe dari berpikir ini digunakan untuk menghasilkan banyak ide dari berbagai macam yang asli, luar biasa dan unik, sedangkan dalam waktu yang sama berguna dan efektif.

Ilmu Pengetahuan Alam (IPA) pada hakekatnya berkaitan dengan cara mencari tahu tentang alam secara sistematis, sehingga IPA bukan hanya penguasaan kumpulan yang berupa fakta-fakta, konsep-konsep atau prinsip-prinsip saja tetapi juga merupakan suatu proses pemecahan masalah untuk mencari dan mendapatkan informasi dan pengalaman secara nyata dalam kehidupan sehari-hari dengan cara membuat sebuah proyek. Pembelajaran IPA diarahkan untuk Proyek sehingga dapat membantu siswa berlatih berpikir kreatif dalam memperoleh pemahaman dan informasi sebuah konsep ataupun fakta-fakta tersebut.

Hasil dari tes berpikir kreatif siswa melalui perhitungan $<\mathrm{g}>$ sebagian besar siswa peningkatannya berkategori sedang dengan rata-rata peningkatan adalah 0,62 yaitu sebanyak 35 siswa dan hanya 4 Siswa yang peningkatannya tinggi dengan rata-rata peningkatan 0,8 . Hasil peningkatan menunjukkan bahwa siswa memiliki respon yang baik dalam pembelajaran Model Proyek. Hal ini sesuai dengan penelitian (Yeuyu, 2010) menyatakan pembelajaran proyek meningkatkan kemampuan kreatif siswa.

Peningkatan dengan kategori sedang disebabkan oleh beberapa hal diantaranya: (1) tidak ada latihan secara kontinu yang dilakukan siswa untuk menguasai keempat indikator ketrampilan berpikir kreatif; (2) keterbatasan waktu sehingga tidak ada pemantauan terhadap ketrampilan berpikir kreatif siswa, karena siswa yang telah selesai menyelesaikan proyek dianggap telah menguasai ketrampilan berpikir kreatif. Peningkatan nilai berpikir kreatif mempunyai kriteria sedang karena untuk meningkatkan kreativitas membutuhkan waktu yang cukup untuk berlatih, hal ini didukung oleh hasil penelitian Chung dkk (2004), yang menyatakan bahwa "The problem-solving instruction showed a marked effect on originally, whereas the other creativity subareas, including fluency and flexibility, showed just a slightly higher average not large enough to be statistically significant. The reason for not showing a statistically significant difference in fluency and flexibility migh be the sort period of theexperiment's duration. Therefore using problemsolving instruction in the long term can also have an effect on other subareas of creativity".

Nilai rata-rata berpikir kreatif didapatkan bahwa nilai-nilai rata-rata pretest adalah 40 yang berkategori kurang kreatif, dikarenakan sebagian besar siswa belum dapat mengeluarkan ide yang beragam dan benar karena materi belum dijelaskan, sehingga siswa banyak yang merasa kesulitan. Nilai rata-rata postest berpikir kreatif adalah 77 yang berkategori kreatif dengan perincian 9 siswa berkategori sangat kreatif dan 30 siswa berkategori kreatif yang terdapat pada gambar 3, hal ini dikarenakan saat proses pembelajaran proyek, siswa sudah mulai dapat mandiri, lancar dalam mengeluarkan ide, mengeluarkan banyak gagasan yang benar, mampu membuat langkah-langkah kerja dalam LKP secara mandiri dan mampu mengerjakan proyek dengan baik. Sebagaimana menurut (Filsaime, 2008) kelancaran adalah kemampuan mengeluarkan ide atau gagasan yang benar dan sebanyak mungkin secara jelas.

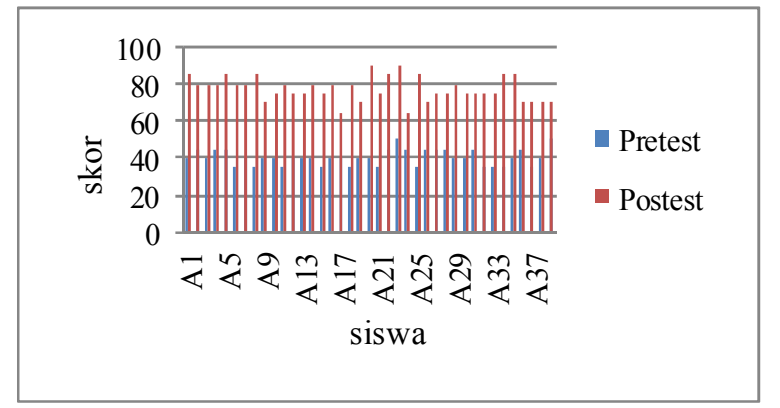

Gambar 3. Diagram Batang Nilai Berpikir Kreatif

Hasil penelitian yang diperoleh bahwa terdapat 4 siswa yang memperoleh peningkatan $<\mathrm{g}>$ lebih tinggi yaitu sebesar 0,8 dikarenakan selama proses pembelajaran proyek yang sedang berlangsung, keempat siswa selalu aktif melakukan aktivitas proyek yaitu membuat proyek, mempersiapkan alat dan bahan, merumuskan masalah, merumuskan hipotesis, mendefinisian variabel, menjadi penanggung jawab setiap kegiatan, menyebutkan langkah kerja proyek, menghasilkan data kerja proyek, menganalisis data, memvariasi hasil dan pembahasan data, merumuskan kesimpulan hasil pengamatan yang terdapat di dalam lembar kerja proyek siswa mulai dari proyek I yaitu menggambar arah gerak suatu perjalanan serta dapat menghitung kecepatannya, proyek II mampu menghitung kecepatan pada gerak lurus beraturan, proyek III mampu menghitung kecepatan dan percepatan pada gerak lurus berubah beraturan, sehingga kemampuan dalam mengerjakan proyek ini mengakibatkan keempat siswa juga mampu mengerjakan tes berpikir kreatif. Banyaknya aktivitas yang dilakukan oleh siswa selama proses pembelajaran, dapat lebih meningkatkan terhadap materi karena siswa mendapatkan pengalaman langsung dan nyata yang dapat mengakibatkan pengetahuan permanen. (Gulbahar \& Tinmaz, 2006: 309).

Siswa lain yang memperoleh nilai peningkatan Ngain $<0,7$ dikarenakan siswa sudah aktif mengerjakan proyek yang terdapat di dalam lembar kerja proyek mulai dari proyek I sampai proyek III tetapi siswa ini masih mengandalkan bantuan dari teman untuk mengerjakan, ini dipengaruhi oleh faktor intelegensia setiap siswa yang berbeda-beda, sehingga perolehan 
hasil tes berpikir kreatif untuk peningkatan $\mathrm{N}$-gain < 0,7. Hasil ini sesuai dengan (William, 1978 dalam Munandar, 2009) bahwa siswa harus mengembangkan kemampuan berpikir kreatif terhadap materi yang diajarkan di sekolah dengan didukung oleh kognitif dan afektif dari siswa.

Indikator tes kreatif mengalami peningkatan seperti yang terdapat pada gambar 4 , dimana pada penelitian ini indikator yang mengalami peningkatan $<\mathrm{g}>$ tertinggi yaitu indikator Flexibility dikarenakan siswa mampu terlatih di dalam pembelajaran proyek untuk menggunakan berbagai macam pendekatan dalam mengatasi masalah, sedangkan yang mengalami peningkatan $<\mathrm{g}>$ terendah pada indikator Elaboration dikarenakan masih ada siswa yang belum mengeluarkan ide yang baru secara terperinci, hal ini bergantung kepada kapasitas siswa untuk menggunakan kognitifnya karena jenis soal yang diberikan dalam berpikir kreatif adalah soal berkategori tinggi menurut taksonomi Bloom sehingga memberikan kesempatan kepada siswa untuk memperluas proses-proses pemikirannya dalam menganalisis, mensintesis dan juga mengevaluasi.

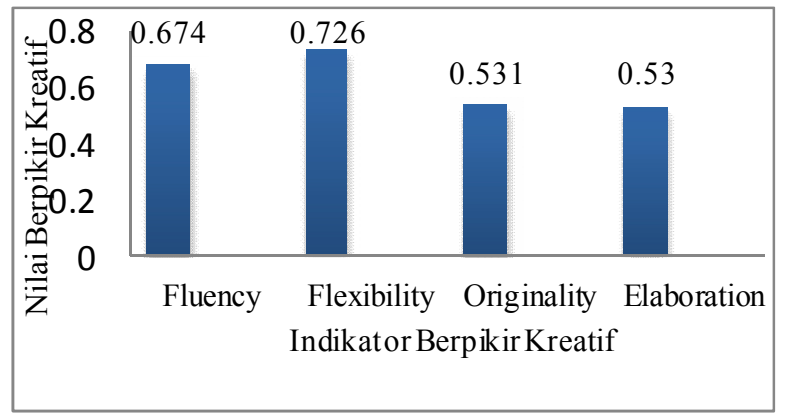

Gambar 4. Diagram Batang Perbandingan Rata-Rata

Skor Gain yang dinormalisasi $<\mathrm{g}>$ setiap

Indikator Berpikir Kreatif

Proses melatih berpikir kreatif siswa melalui fasilitas Handout dan LKP yang dikembangkan terdapat langkah-langkah melatih berpikir kreatif siswa. Handout dan LKP yang dikembangkan dengan model pembelajaran proyek untuk mengetahui berpikir kreatif siswa, Guilford (1950) menyatakan berpikir kreatif adalah kemampuan untuk melihat berbagai macam kemungkinan menyelesaikan suatu masalah. Dyers et al. (2011) menyatakan bahwa kemampuan berpikir kreatif adalah hasil belajar, bukan anugerah genetik sehingga diperlukan bahan ajar untuk melatihkan berpikir kreatif siswa. Model yang digunakan dalam pembelajaran ini adalah model pembelajaran proyek yang dapat digunakan untuk melatihkan berpikir kreatif siswa (Sugiyastini, 2013).

Tes berpikir kreatif diukur dengan menggunakan tes Torrance (1984) yang menentukan empat karakteristik dari berpikir kreatif yang diadaptasi sesuai dengan materi yang diajarkan yaitu gerak benda. Kategori ditentukan sesuai dengan tanggapan untuk menguji jawaban yang diberikan siswa dan skor yang diberikan sesuai dengan rubrik penskoran.

\section{Respon Siswa}

Respon siswa yang dihasilkan terlihat bahwa 39 siswa selama mengikuti pembelajaran model proyek secara umum menyatakan suka terhadap komponen perangkat pembelajaran meliputi (materi pelajaran, model pembelajaran proyek, lembar kerja proyek, media pembelajaran, penilaian sikap, penilaian pengetahuan, penilaian ketrampilan, dan proyek yang dikerjakan) adalah $89 \%$ dan yang menyatakan tidak suka adalah $11 \%$.

Hasil respon siswa yang menyatakan setuju terhadap pembelajaran model proyek sebesar $94 \%$ karena siswa menyatakan pendapatnya bahwa pembelajaran proyek memudahkan untuk mempelajari materi gerak benda dengan metode menggunakan alat peraga gambar milimeter blok untuk membedakan antara jarak dengan perpindahan, membedakan antara kelajuan dengan kecepatan menggunakan alat peraga air dan minyak dalam pipa kapiler, siswa juga menyatakan pembelajaran proyek mengasah kemampuan diri untuk berpikir kreatif mencari pengetahuan yang belum diketahui oleh siswa. Siswa yang menyatakan tidak setuju terhadap pembelajaran model proyek sebesar 6\%. Rata-rata respon siswa pada kelas VIII A yang suka dengan kegiatan pembelajaran ini adalah $92 \%$ dan yang tidak suka adalah $8 \%$.

Siswa yang merasa suka terhadap pembelajaran model proyek dapat dilihat pada aktivitas dalam pembelajaran, yang meliputi siswa tersebut memperhatikan saat guru menjelaskan, menyebutkan langkah kerja proyek, merumuskan masalah dan hipotesis, melaksanakan percobaan terhadap hasil proyek, membuat grafik terhadap hasil proyek, dan menyimpulkan hasil percobaan proyek dengan benar.

Siswa yang memiliki respon yang kurang baik berarti siswa tersebut kurang aktif dalam kegiatan pembelajaran model proyek. Respon siswa pada pembelajaran ini sebagian besar memiliki respon yang positif, hal ini senada dengan penelitian Munawaroh (2013) bahwa tanggapan siswa terhadap pembelajaran dengan menggunakan model proyek diketahui sangat baik.

\section{Kendala-Kendala Selama Proses Pembelajaran}

Hambatan yang dihadapi siswa berdasarkan masukan dari pengamat dan peneliti bahwa pada pertemuan pertama, siswa mengalami kesulitan dalam merumuskan suatu hipotesis dan variabel penelitian saat mengerjakan Lembar Kerja Proyek dengan benar sehingga memerlukan bimbingan dari guru. Hambatan pada pertemuan kedua, siswa masih kesulitan dalam merumuskan hipotesi dan belum dapat menggambarkan grafik kecepatan-waktu, sehingga guru memberikan 
penjelasan dan bimbingan. Hambatan pada pertemuan ketiga, siswa kesulitan menganalisis data untuk menghitung percepatan pada materi GLBB, sehingga guru membimbing siswa cara menghitung percepatan GLBB.

\section{KESIMPULAN}

\section{A. Simpulan}

Perangkat pembelajaran model proyek untuk melatihkan berpikir kreatif siswa SMP yang telah dikembangkan valid, praktis, dan efektif.

\section{B. Saran}

Berdasarkan penelitian yang telah dilakukan dan hasil yang didapat disarankan hal-hal sebagai berikut: Penerapan model pembelajaran proyek dapat melatihkan berpikir kreatif siswa dengan peningkatan kategori sedang dikarenakan proses penerapannya hanya dalam waktu pendek, hendaknya peneliti lebih lanjut melakukan penelitian dalam jangka waktu yang lebih lama untuk mendapatkan peningkatan berpikir kreatif dengan kategori tinggi; Penerapan model pembelajaran proyek dapat melatihkan berpikir kreatif siswa, dengan melakukan penyebaran perangkat pembelajaran proyek disarankan para teman guru yang lain dapat mengimplementasikannya dalam proses pembelajaran; Mengingat penelitian ini hanya dilakukan pada materi Gerak dan Kecepatan, Gerak Lurus Beraturan (GLB) dan Gerak Lurus Berubah Beraturan (GLBB), maka perlu dilakukan penelitian lebih lanjut yang serupa pada materi lain; Pengetahuan prosedural siswa dalam melakukan proyek membutuhkan perhatian dengan frekuensi yang lebih banyak dari guru sebagai pendukung dalam melatihkan berpikir kreatif siswa.

\section{REFERENSI}

Asmani, J.M. (2013). Pembelajaran aktif, kreatif, efektif, dan menyenangkan. Jogjakarta. DIVA Press. 2013.

Borich, G. D. (2000). Effective teaching methods (4 $4^{\text {th }}$ ed). New Jersey: Prentice-Hall, Inc.

Carin, A.A. (1993), Teaching Science Through Discovery. Toronto: Meerll Publising Company.

Chung, N. \& Ro.G. (2004). "The Effect of Problem Solving Instruction on Children's Creativity Self-efficacy in the Teaching of the Practical Arts Subyect". The Journal of Technology Studies : 116-122.

Daryanto. (2009). Panduan Proses Pembelajaran Kreatif dan Inovatif. Teori \& Praktik dalam Pengembangan Profesionalisme Bagi Guru. Jakarta: Publiser.
Diamond, I. (2006). Science Education in Schools. The Association for Science Education.

Direktorat Jenderal Pendidikan Tinggi, Kemdikbud. (2013). Permendikbud no 322013 tentang perubahan atas Peraturan Pemerintah Nomor 19 Tahun 2005 tentang Standar Nasional Pendidikan . Jakarta. Kemdikbud.

Dyer, J., Gregesen, H., Clayton, M., Christensen. (2011). The Innovator's DNA. Boston, Massachusetts: Harvard Business Review Press.

Filsaime, Dennis K. (2008). Menguak rahasia berpikir kritis dan kreatif. Jakarta. PT. Prestasi Pustakaraya.

Guilford. (1950). Creativity Research: Past, Present and Future. Journal American Psychologist $\mathrm{p}$ 444-454.

Gülbahar Y, dan Tinmaz H. (2006). "Implementing Project-Based Learning And E-Portfolio Assessment In an Undergraduate course". Journal of Research on Technology in Education. Volume 38, Number 3. Page 309327.

Khaeruddin dan Hadi Sujiono,Eko. (2005). Pembelajaran Sains (IPA). Makasar. Universitas Negeri Makasar

Klieger, A. \& Sherman, G. (2015). "Physics Education". Tersedia pada Http://Www.Eric.ed.gov/?Journals. Diakses Pada Tanggal 31 Juli 2015.

Liu, W.C. (2007)."Project-Based Learning and Students Motivation". Tersedia pada Http://Www.Google.Co.Id/Project-BasedLearning-Journalfiletype: Pdf. Diakses Pada Tanggal 22 April 2015.

Munandar, U. (2009). Pengembangan Kreativitas Anak Berbakat. Jakarta: Rineka Cipta.

Munawaroh, A. (2013). "Penerapan Model Pembelajaran Berbasis Proyek untuk Meningkatkan Hasil Belajar Sistem Pencernaan SMP”. Jurusan Biologi FMIPA Universitas Negeri Semarang. Unnes Journal of Biology Education.

Rohim, F., Hadi,S., Ellianawati. (2012). "Penerapan Model Discovery Terbimbing Pada Pembelajaran Fisika Untuk Meningkatkan Kemampuan Berpikir Kreatif”. Unnes Physics Education Journal. http://journal. Unnes.ac.id/sju/index.php/upej. Diakses 23 September 2013.

Slavin, E.R. (2006). Psikologi pendidikan: Teori dan Praktik Edisi Kesembilan, jilid 1. Jakarta Barat: Indeks. 
(2006). Psikologi pendidikan: Teori dan Praktik Edisi Kesembilan, jilid 2. Jakarta Barat: Indeks.

Sugiyastini,W.,Sudana,D.N， Suartama,I.K. (2013). "Pengaruh Model Pembelajaran Berbasis Proyek Terhadap Kemampuan Berpikir Kreatif Siswa Pada Mata Pelajaran IPA Kelas V SD
Gugus V Banjar”. Jurusan PGSD Universitas Pendidikan Ganesha Singaraja. Jurnal Penelitian IPA.

Yueyu, X. \& Wengi, L. (2010). “A Project-Based Learning Approach". Tersedia pada Http://Www.Eric.ed.gov/?Journals. Diakses Pada Tanggal 31 Juli 2015. 